\title{
PHASE RELATIONSHIPS IN SEA ICE AS A FUNCTION OF TEMPERATURE
}

\author{
By C. Richardson \\ (Arctic Submarine Laboratory, Naval Undersea Center, San Diego, California $9213^{2}$, \\ U.S.A.)
}

\begin{abstract}
Quantitative measurements of the liquid water phase in a sample of sea ice were made with a nuclear magnetic resonance spectrometer. The measurements are used to compute the phase relationships in sea ice as a function of temperature. A model for sea-water based upon a mixture of seven binary salts is used for these computations. The n.m.r. measurements are related to the solvation water which is associated with each binary salt. This solvation water is bound to the salt in a pseudo-crystalline structure, with the amount of water determined by the eutectic concentration of the salt. The results are given in tabular form and differ somewhat from previously published tables. Two controversial hydrated salts were added to the table, based on the n.m.r. data.
\end{abstract}

RÉsumÉ. Relations entre phases dans la glace de mer en fonction de la temperature. Les mesures quantitatives de la phase de l'eau liquide dans un échantillon de la glace de mer ont été faites avec un spectromètre nucléaire à résonnance magnétique. Les mesures sont utilisées à calculer les relations entre phases dans la glace de mer en fonction de la température. Un modèle d'eau de mer basé sur un mélange de sept sels binaires est employé pour ces calculs. Les mesures de R.M.N. sont en relation avec l'eau de dissolution qui est associée à chaque sel binaire. Cette eau de dissolution est liée au sel dans une structure pseudo-cristalline, la quantité d'eau étant déterminée par la concentration eutectique du sel. Les résultats sont donnés sous forme de tableau et sont un peu différents des tables publiées auparavant. Sur la base des données R.M.N., deux sels hydrates controversés ont été rajoutés à la table.

Zusammenfassung. Phasenbeziehungen im Meereis als Funktion der Temperatur. Quantitative Messungen der flüssigen Wasserphase in einer Meereisprobe wurden mit einem kernmagnetischen Resonanzspektrometer vorgenommen. Die Messungen werden dazu benutzt, die Phasenbeziehungen im Meereis als Funktion der Temperatur zu berechnen. Ein Modell für Meerwasser auf der Grundlage eines Gemenges vor sieben Zweistoff-Salzen wird für diese Berechnungen benutet. Die kernmagnetischen Resonanzmessungen sind abhängig von dem Lösungswasser, das in jedem der Zweistoff-Salze vorkommt. Dieses Lösungswasser ist in Form einer Pseudokristall-Struktur an die Salze gebunden, wobei seine Menge durch die eutektische Konzentration des Salzes bestimmt ist. Die Ergebnisse sind in tabellarischer Form dargestellt; sie unterschieden sich etwas von früher herausgegebenen Tabellen. Ziwei zweifelhafte hydratische Salze wurden aufgrund der kernmagnetischen Resonanzmessungen in die Tabelle mit aufgenommen.

\section{INTRODUCTION}

If a sample of sea-water is placed in a container and subjected to sub-freezing temperatures, a series of quasi-equilibria develop (one at each temperature value). These equilibria are formed between the solid phases of ice and precipitated salts, and the liquid phase, brine. Such a closed system represents the entrapped brine cells in actual sea ice. The quantity, composition, and distribution of these cells affect the behavior and physical properties of sea ice, and therefore have interested Arctic scientists for many years.

In 1937 Gitterman (1937) published the first comprehensive quantitative analysis of the solid and liquid phases of a sample of sea-water as a function of sub-freezing temperatures. Gitterman not only succeeded in computing the liquid and solid phases, he also computed the quantities of four of the hydrated salts. In 1954 Nelson and Thompson (1954) analyzed the residual brine from frozen samples of sea-water. They determined the relative amounts of each of the six major ions and the amount of residual brine. These data were used by Assur (1958) to compute quantitative values for the six major ions, six hydrated salts, and ice in equilibrium at temperatures down to $-54^{\circ} \mathrm{C}$. Assur also made use of some quantitative data published by Ringer ( 1906, I928). Ringer's work with concentrated and artificial brines gives the only data reported for temperatures below $-43^{\circ} \mathrm{C}$.

In 1966 the author, with E. Keller, published data on the total liquid-water content of a sea-water sample at sub-freezing temperatures (Richardson and Keller, I966). These data were collected from measurements made with a nuclear magnetic resonance spectrometer. Assuming the residual and entrapped brine had the same ion content, the water data were 
used to compute the total amount of brine present at each quasi-equilibrium. However, the sensitivity of the n.m.r. spectrometer and associated equipment limited the temperature range for accurate results to $-25^{\circ} \mathrm{C}$. When new n.m.r. equipment became available, the project was resumed in an effort to remove some of the ambiguities reported at lower temperatures. A new, more sensitive calibration system and signal-averaging equipment extended the range of water measurements to $-5 \mathrm{I}^{\circ} \mathrm{C}$. The measurements were then combined with the experimental data on ion ratios and solubility curves to compute a table of phase relationships similar to Assur's (1958) table 3.

\section{Theory}

The basic n.m.r. theory of liquid-water measurement was presented in Richardson and Keller (1966). From this reference the final equation for the percentage of liquid-water content in a sample is given by

$$
w=\frac{A_{\mathrm{s}}\left(\mathrm{I}-S_{\mathrm{c}}\right)}{A_{\mathrm{c}}} \frac{\rho_{\mathrm{c}}}{\rho_{\mathrm{s}}}
$$

where $A_{\mathrm{s}}$ is the area under the n.m.r. absorption curve of the sample, $A_{\mathrm{c}}$ the area under the n.m.r. absorption curve of the comparative solution, $S_{\mathrm{c}}$ the salinity of the comparative solution, $\rho_{\mathrm{c}}$ the density of the comparative solution, and $\rho_{\mathrm{s}}$ the density of the sample.

This equation was used to compute the amount of liquid water in the sea-ice samples at each temperature. Two comparative solutions were used: one, a eutectic solution of $29.868 \%$ calcium chloride; the second, a $3.507 \%$ solution of calcium chloride. The two comparative solutions were used at each temperature to calculate two values of the water content for each

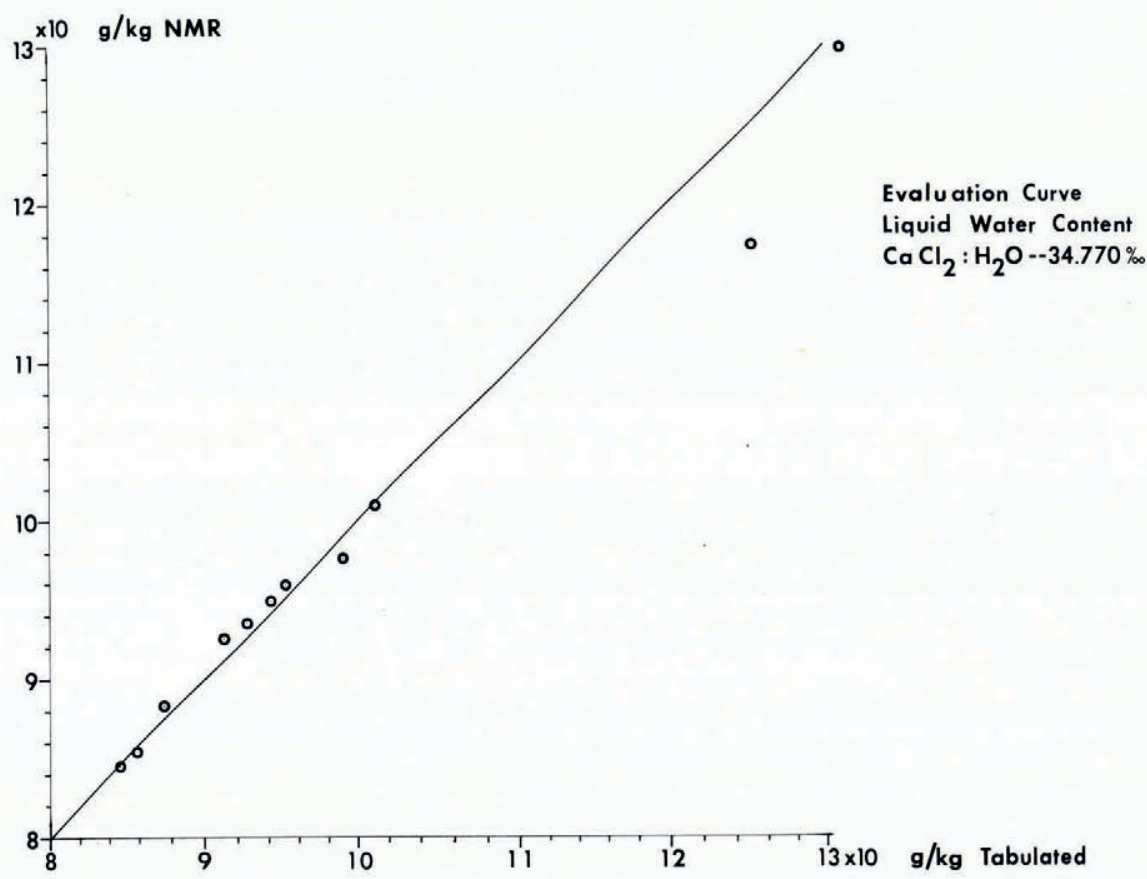

Fig. I. Eicaluation curie of liquid water content of a salt solution measured by an n.m.r. spectrometer. Temperature range is $-18^{\circ} \mathrm{C}$ to $-51 \mathrm{C}$. 
sample measurement. This system provided compensation for ice effects and a check on the electronic amplification calibration. One comparative solution had about the same salt content as the sea-water samples; therefore their n.m.r. signals tended to be about the same strength and have the same ice-broadened shape. The eutectic solution, on the other hand, formed no ice and had n.m.r. signals one hundred to a thousand times stronger than the sample. These strong signals required attenuation.

In order to evaluate Equation ( $\mathrm{I}$ ), several test curves were run. These evaluation curves were run on refrigeration brines such as sodium chloride and calcium chloride. These brines have tabulated values for salt concentration at sub-freezing temperatures and, consequently, known values of water content as a function of temperature. Figure $\mathrm{I}$ is typical of the graphs obtained for a single sample at various temperatures. Other curves were obtained by using five solutions of different concentrations and measuring the water content at one temperature. All of the evaluation graphs had correlation coefficients of $99 \%$ or better.

\section{EXPERIMENTAL ARRANGEMENT}

The nuclear magnetic resonance spectrometer was a Varian DP-6o, with external lock for proton stabilization. The spectrometer also included an electronic integrator. Sample size was $0.4 \mathrm{I} \mathrm{cm}^{3}$, placed in a spinning dewar, with the entire sample within the active volume of the receiver coil. A Nicolet Io7o signal averager was used for signal enhancement at low temperatures. Temperature control was maintained stable within $\pm 0 . \mathrm{r}$ deg. Temperature accuracy was $\pm 0.3 \mathrm{deg}$ at the sample, since no thermocouple could be placed near the sample, i.e. within the n.m.r. radiofrequency field. All samples and comparative solutions were de-gassed and the atmosphere replaced with dry nitrogen.

\section{Discussion}

The phase distribution tables of Gitterman (1937) and Assur (1958) have the same format as Table I. They differ from Table I and from each other in the quantities and types of salts formed. The phase distribution table presented by Assur (1958, table 3) was calculated with the aid of one of the standard curves of freezing point versus salt content (Anderson, I960, fig. I) and the solutions of a great many mass-balance equations for the various ions. The quantitative data on ions used in these computations came from the experiments of Ringer (1906) and Nelson and Thompson (1954). Gitterman (1937, table 12) appears to have performed the same quantitative measurements of the ions in the residual brine as Nelson and Thompson did. He then made calculations similar to Assur's and published a table of phase relationships. Gitterman's table 12 included the six major ions, four salts, and the quantities of ice, brine and water present at each temperature of his experiments. One of Gitterman's salts, $\mathrm{CaSO}_{4} \cdot{ }_{2} \mathrm{H}_{2} \mathrm{O}$, is not mentioned in any of the works referenced above. However, Savel'yev ( ${ }_{9} 63[\mathrm{a}]$, [b]) reports on $\mathrm{CaSO}_{4} \cdot{ }_{2} \mathrm{H}_{2} \mathrm{O}$ precipitation from sea-water beginning at $-17^{\circ} \mathrm{C}$, and Thompson and Nelson (1956) mention it in connection with iceblocked bays.

Savel'yev ( $1963[\mathrm{a}])$ used the reaction equation,

$$
\mathrm{CaSO}_{4}+2 \mathrm{NaCl}=\mathrm{CaCl}_{2}+\mathrm{Na}_{2} \mathrm{SO}_{4}
$$

to describe the situation. Precipitation of $\mathrm{Na}_{2} \mathrm{SO}_{4}$ causes a rightward displacement of the above reaction. At $-17^{\circ} \mathrm{C}$ the equation reverses and a precipitation of $\mathrm{CaSO}_{4}$ induces a leftward displacement, whereupon the precipitation of $\mathrm{Na}_{2} \mathrm{SO}_{4}$ ceases. This binary salt model was used to account for the results obtained by Gitterman (1937). At $-17^{\circ} \mathrm{C}$ Gitterman's table 12 shows $\mathrm{CaSO}_{4}$ beginning to precipitate and $\mathrm{Na}_{2} \mathrm{SO}_{4}$ redissolving (see Fig. 2). 
TABle I. The Distribution OF IONS, WATER, HYDRATED SAlts, AND ICE THAT CONSTITUTE THE QUASI-EQUILIBRIUM CONDITIONS IN A ONE KILOGRAM SAMPLE OF COPENHAGEN SEA-WATER AT SUB-FREEZING TEMPERATURES

Sea-water chlorinity $19.373 \%$; sea-water salinity $-34.998 \%$

Tem-

$\begin{array}{cc}\begin{array}{c}\text { perature } \\ \text { C }\end{array} & \mathrm{K} \\ 0.0 & 0.387 \\ -2 & \\ -4 & \\ -6 & \\ -8 & \\ -10 & \\ -12 & \\ -14 & \\ -16 & \\ -18 & \\ -20 & \\ -22 & \\ -24 & \\ -26 & \\ -28 & \\ -30 & \\ -32 & \\ -34 & 0.336 \\ -36 & 0.309 \\ -38 & 0.281 \\ -40 & 0.251 \\ -42 & 0.209 \\ -44 & 0.100 \\ -46 & 0.039 \\ -48 & 0.015 \\ -50 & 0.009 \\ -52 & 0.008\end{array}$

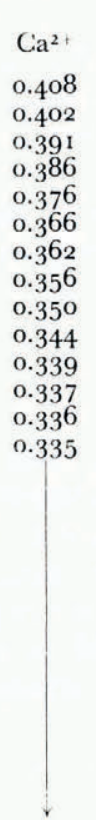

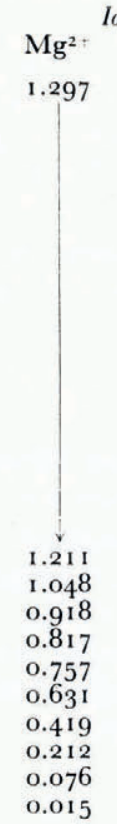
lons

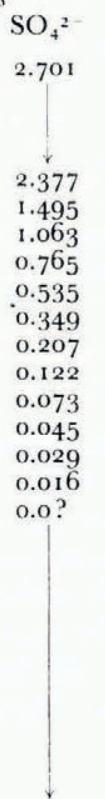

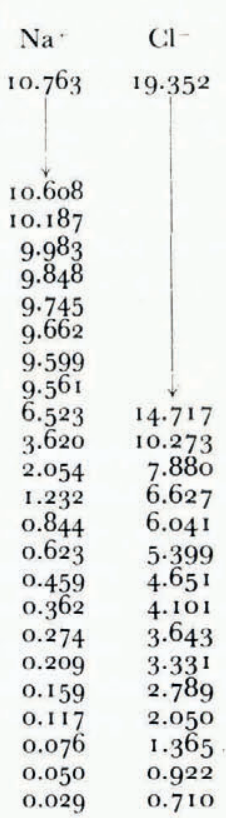

Unknown
o.090
0.081
0.065
0.057
0.042
0.030
$\mid$


0.027
0.024
0.021
0.019
0.016
0.013
0.010
0.007
0.005
$0.0 ?$

$\begin{aligned} & \text { Total } \\ & \text { ions }\end{aligned}$
34.998
34.983
34.956
34.943
34.439
33.114
32.474
32.035
31.696
31.421
31.211
31.086
23.363
15.984
12.006
9.915
8.923
7.920
6.815
6.007
5.327
4.848
4.014
2.960
2.003
1.392
1.097

Total

Liquid water

965.002 860.825 488.714 335.001 247.534 196.921 173.412 I 54.769 139.783 127.042 I 16.225 106.673 $77.48 \mathrm{I}$ 52.347 39.177 32.104 27.397 23.393 19.720 17.005 14.893 1 3.507 10.988 7.804 $5.15^{\circ}$ 3.404 2.645
Brine salinity 34.998 $39.05^{2}$ $66.75^{2}$ 94.455 122.135 $143.95^{2}$ 157.728 171.490 184.839 198.286 211.685 225.655 231.675 233.905 234.570 235.966 245.677 252.930 256.830 261.038 $263.45^{2}$ 264.044 267.564 274.99 I 280.022 290.242 293. 159

\begin{tabular}{|c|c|c|c|c|c|c|c|c|c|c|}
\hline $\begin{array}{c}\text { Tem- } \\
\text { perature } \\
{ }^{\circ} \mathrm{C}\end{array}$ & $\begin{array}{l}\mathrm{CaCO}_{3} \\
.6 \mathrm{H}_{2} \mathrm{O}\end{array}$ & $\begin{array}{l}\mathrm{Na}_{2} \mathrm{SO}_{4} \\
\cdot{ }_{1} \mathrm{OH}_{2} \mathrm{O}\end{array}$ & $\begin{array}{l}\mathrm{CaSO}_{4} \\
\cdot{ }_{2} \mathrm{H}_{2} \mathrm{O}\end{array}$ & $\begin{array}{l}\mathrm{NaCl} \\
\cdot{ }_{2} \mathrm{H}_{2} \mathrm{O}\end{array}$ & KCl & $\begin{array}{c}\mathrm{MgCi}_{2} \\
\cdot{ }_{1} 2 \mathrm{H}_{2} \mathrm{O}\end{array}$ & $\begin{array}{l}\mathrm{MgCll}_{2} \\
\cdot 8 \mathrm{H}_{2} \mathrm{O}\end{array}$ & $\begin{array}{l}\text { Unknown } \\
\text { salts }\end{array}$ & $\begin{array}{l}\text { Salts' } \\
\text { water }\end{array}$ & Ice \\
\hline 0.0 & 0.000 & 0.000 & 0.000 & 0.000 & 0.000 & 0.000 & 0.000 & 0.000 & 0.000 & 0.000 \\
\hline-2 & $0.03 \mathrm{I}$ & & & & & & & & 0.016 & $104.16 \mathrm{I}$ \\
\hline-4 & 0.088 & & & & & & & & 0.046 & 476.242 \\
\hline-6 & 0.115 & & & & & & & & 0.060 & $629.94^{1}$ \\
\hline-8 & 0.166 & 1.086 & $\vee$ & & & & & & 0.693 & 716.775 \\
\hline-10 & 0.208 & 4.029 & 0.009 & & & & & & 2.362 & 765.719 \\
\hline-12 & & $5.45^{2}$ & 0.024 & & & & & & 3.161 & 788.429 \\
\hline-14 & & 6.402 & $0.05 \mathrm{i}$ & & & & & & 3.698 & 806.535 \\
\hline-16 & & 7.121 & 0.078 & & & & & & 4.105 & 821.114 \\
\hline-18 & & 7.698 & o. 104 & & & & & & 4.433 & $833.5^{27}$ \\
\hline-20 & & 8.137 & o. 124 & & & & & & 4.682 & 844.095 \\
\hline-22 & & 8.403 & o. 134 & $\downarrow$ & & & & & 4.833 & 853.496 \\
\hline-24 & & 8.556 & o. 139 & 12.360 & & & & $\downarrow$ & 9.629 & $877.89^{2}$ \\
\hline-26 & & 8.647 & 0.141 & $24.21 \mathrm{I}$ & & . & & 0.003 & 14.196 & 898.459 \\
\hline-28 & & 8.709 & & $30.59^{2}$ & & & & 0.006 & 16.663 & 909.162 \\
\hline-30 & & $8.74^{8}$ & & 33.934 & & & & 0.009 & 17.956 & 914.942 \\
\hline$-3^{2}$ & & 8.799 & & 35.497 & $\checkmark$ & $\checkmark$ & & 0.011 & 18.581 & 919.024 \\
\hline-34 & & & & $3^{6.403}$ & 0.101 & 1.106 & & 0.014 & I 9.694 & $921 \cdot 9$ I 5 \\
\hline-36 & & & & 37.075 & o. $14^{8}$ & 3.198 & & 0.017 & 21.401 & $9^{23} .879$ \\
\hline$-3^{8}$ & & & & $37 \cdot 47 \mathrm{I}$ & 0.201 & $4.85^{2}$ & & 0.020 & 22.701 & 925.296 \\
\hline-40 & & & & 37.833 & 0.259 & 6.147 & & 0.023 & $23.73^{8}$ & 926.371 \\
\hline$-4^{2}$ & & & & $3^{8.098}$ & 0.339 & 6.912 & $r$ & 0.025 & $24 \cdot 345$ & 927.125 \\
\hline-44 & & & & 38.302 & $0.54^{6}$ & 7.234 & 0.994 & 0.030 & 25.269 & $9^{28.745}$ \\
\hline-46 & & & & 38.474 & $0.66_{3}$ & & 3.083 . & & 26.593 & 930.605 \\
\hline$-4^{8}$ & & & & $38.64^{2}$ & 0.708 & & 5.116 & & 27.883 & $93^{1} \cdot 969$ \\
\hline$-5^{\circ}$ & & & & $38.75^{1}$ & 0.720 & & $6.45^{1}$ & & 28.727 & $93^{2.871}$ \\
\hline$-5^{2}$ & $\downarrow$ & $\checkmark$ & $\checkmark$ & $3^{8.8} 3^{6}$ & 0.722 & v & 7.055 & $\checkmark$ & 29.123 & 933.234 \\
\hline
\end{tabular}




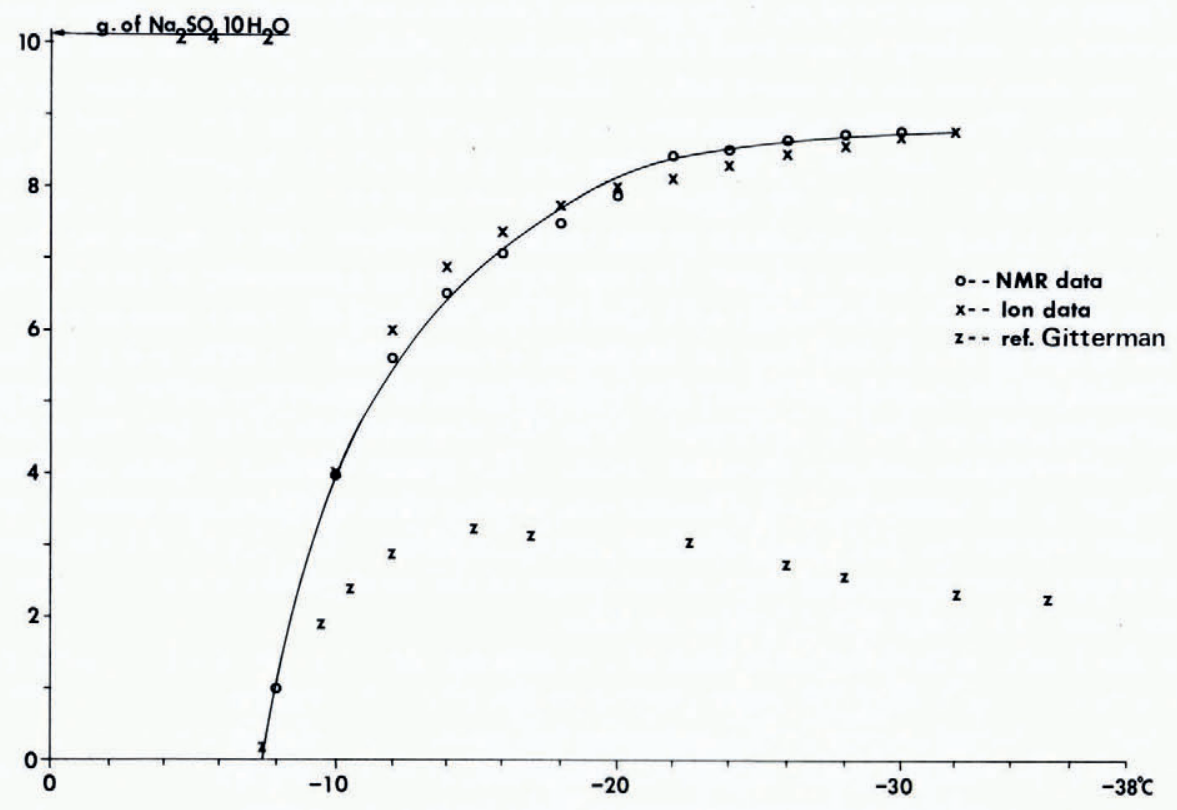

Fig. 2. The precipitation curve for $\mathrm{Na}_{2} \mathrm{SO}_{4} \cdot \mathrm{OH}_{2} \mathrm{O}$. The curve is a fourth-order regression of the points, calculated from the n.m.r. data. $R^{2}$ is $0.9^{8}$. Ref. Gitterman refers to Gitterman's table 12 (1937).

These data are not substantiated by the Nelson and Thompson (1954) data, which show a continuous loss of $\mathrm{Na}^{+}$from $-8.3^{\circ} \mathrm{C}$ to $-23^{\circ} \mathrm{C}$ (the eutectic temperature of $\mathrm{NaCl}$ ). Mellor (1922-37) reports on the solubility of many cryohydrates, including $\mathrm{Na}_{2} \mathrm{SO}_{4}$, but makes no mention of any salt redissolving upon a negative change in temperature. Mellor (1922-37, Vol. 3) reports on the solubility of $\mathrm{CaSO}_{4}$ down to a temperature of $-7^{\circ} \mathrm{C}$. However, no eutectic temperature is given. Unfortunately, this is not the only difficulty in setting up the phase relationships: another arises in connection with the two hydrates of a single salt, e.g. magnesium chloride $\left(\mathrm{MgCl}_{2} \cdot \mathrm{I}_{2} \mathrm{H}_{2} \mathrm{O}\right.$ and $\left.\mathrm{MgCl}_{2} \cdot 8 \mathrm{H}_{2} \mathrm{O}\right)$ and sodium sulfate $\left(\mathrm{Na}_{2} \mathrm{SO}_{4} \cdot{ }_{1} \mathrm{H}_{2} \mathrm{O}\right.$ and $\left.\mathrm{Na}_{2} \mathrm{SO}_{4} \cdot{ }_{7} \mathrm{H}_{2} \mathrm{O}\right)$. Assur added the octahydrate to his table, but none of the other authors mention it.

Mellor (1922-37, Vol. I and 3) presents solubility curves for both sodium sulfate and magnesium chloride. Figure 3 is a portion of the magnesium chloride solubility curve. The octahydrate is shown as a quasi-stable form that may or may not be present. A similar set of curves describes sodium sulfate decahydrate and the quasi-stable heptahydrate. The octahydrate of magnesium chloride has a eutectic temperature of $-43^{\circ} \mathrm{C}$, and, since the precipitation of the dodecahydrate is nearing completion, any large increase in the precipitation of a new hydrate will show up as a change in slope of the water curve. This does occur at $-43^{\circ} \mathrm{C}$, as shown in Figure 4. However, it is not evident from $-10^{\circ} \mathrm{C}$ to $-14^{\circ} \mathrm{C}$, where the sodium sulfate heptahydrate would be likely to precipitate. Calculations based on the n.m.r. data for this temperature range rule out any precipitation of the heptahydrate. These calculations and all of the other phase calculations are based on a binary salt mixture model similar in part to the one Savel'yev ( $1963[\mathrm{a}]$ ) proposed with Equation (2). The model for sea-water contains seven binary salts: sodium sulfate, sodium chloride, calcium sulfate, calcium chloride, magnesium chloride, potassium chloride, and calcium carbonate. In order to develop this model, and its characteristic, a single binary salt, magnesium chloride, is used as an example. 
In Figure 3, if a mixture of $20 \%$ magnesium chloride is subjected to a gradual lowering of the temperature, nothing occurs until the temperature reaches $-30^{\circ} \mathrm{C}$. At that temperature the $20 \%$ line intersects the ice curve and ice forms. As the temperature continues to decrease, more ice forms. The solution becomes more concentrated until point B is reached. This is the eutectic point for the dodecahydrate. If only the dodecahydrate is present, then the entire mixture will solidify. The process appears to be a series of alternate freezing of ice and precipitation of salt, more ice, more salts, so that the final conditions are a heterogeneous mixture of ice crystals lying in a matrix of salt. In some mixtures this alternating system is sufficiently regular to result in a lamellar effect with alternating bands of the two components.

In the presence of a second salt, the sequence is interrupted. At some point the increased concentration of the second salt lowers the freezing point of the system below the temperature of the solution and no more ice is formed. Thus the concentration of the first salt is below the eutectic concentration and precipitation ceases. The system reaches a quasi-equilibrium.

In Figure 3 the octahydrate is a second salt, and at each temperature below $-36^{\circ} \mathrm{C}(\mathrm{B})$ more water freezes out and more dodecahydrate solidifies. At $-43^{\circ} \mathrm{C}$ (L) the last of the dodecahydrate precipitates and the concentration of the octahydrate is raised to the eutectic concentration. Then the entire system solidifies.

If a third salt, such as calcium chloride, is present, then the octahydrate only partially precipitates at $-43^{\circ} \mathrm{C}$ and the same process as the first salt underwent is repeated for the second salt. It should be noted that precipitation under these conditions is rarely complete. The precipitation follows a curve similar to a parabola, as shown in Figure 2, until the increase in precipitation is below the detection levels. Of the seven binary salts in the sea-water model, six form hydrates and their behavior follows that of the example above. The basis for this behavior can be found in solvation theory.

One of the models for solvation proposes that surrounding a solute ion there are three regions which can be fairly well distinguished from each other (Conway and Barradas, 1966). Close to the solute ion there is an increase in solvent structure. (For polar solvents one or more layers of solvent molecules are adsorbed on the surface of the solute ion.) Lying outside this

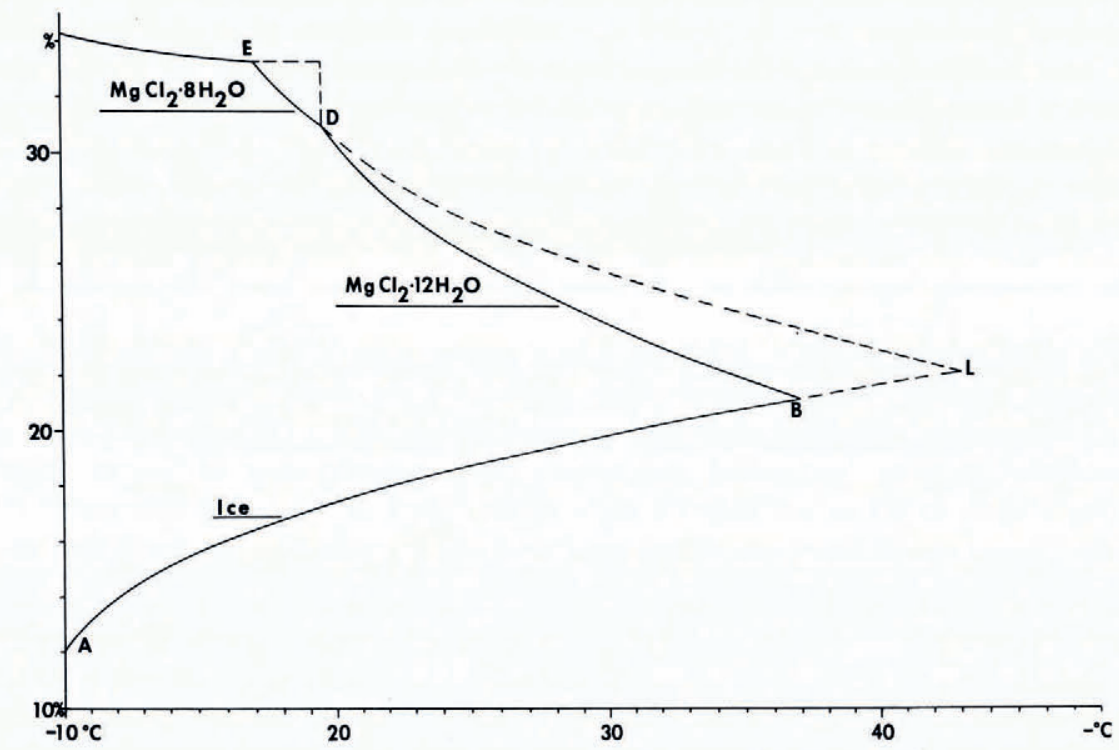

Fig. 3. A portion of the solubility cure for magnesium chloride. Point $B$ is the dodecahydrate eutectic; point $L$ is the eutectic for the octahydrate. 


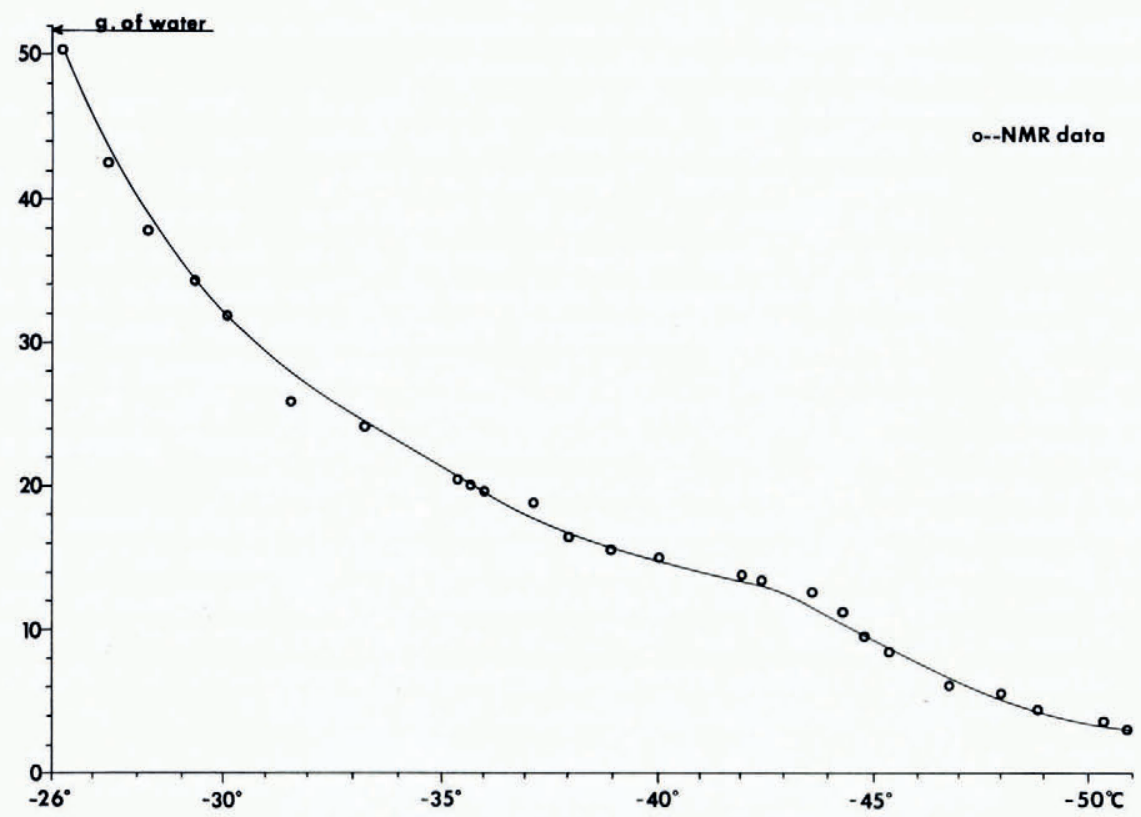

Fig. 4. Liquid water content of a sea-water sample measured by an n.m.r. spectrometer. Cirve is made up of three ranges; each range is a separate fourth-order regression analysis of the data. The squared correlation coefficients, $\left(R^{2}\right)$ are $0.9^{8}$, $0.99,0.99$.

region is an area where the solvent molecules suffer some disordering as the result of the opposing effects of solute and the surrounding solvent molecules. In the third region the solvent molecules are essentially unperturbed by the other two areas.

Not all ion-solvent interactions exhibit hydration. Many salts of the larger monovalent ions $(\mathrm{K}, \mathrm{Au}, \mathrm{Rb})$ are anhydrous. In these cases the water molecules are not bound to the surface of the ion and the ion acts as a structure-disordering species. In sea-water $\mathrm{KCl}$ salt is of this type.

Now, if we assume that the first and second regions of a binary salt molecule constitute a pseudo-crystal-like structure, then in a eutectic solution all of the water molecules are part of this structure and none are available for making ice or precipitate. At the eutectic temperature the pseudo structure can no longer be maintained and ice is formed. Then salt and more ice precipitates alternately, until the entire solution solidifies. In the non-eutectic concentration mixture, the water required to form a eutectic mixture with the reduced concentration is bound and the rest of the water is free to freeze out. Thus, in a binary salt model of seawater, all of the water molecules can be assigned as either bound to one of the salts or free in the outer space. Then, as the temperature is reduced, all of the free water freezes out, and the entire phase distribution at each quasi-equilibrium can be computed on the basis of the amount of bound water remaining. This bound water is measured by means of the n.m.r. spectrometer. Of course, the salt $\mathrm{KCl}$ does not lend itself to such computation since it forms an anhydrous precipitate.

\section{Results}

The results of the n.m.r. studies are summarized in Table $\mathbf{1}$. This table varies considerably from those of Gitterman (1937) and Assur (1958). The initial ion concentrations are based on the ion ratios in so-called "normal sea-water". These are the same ion ratios used by Assur 
(1958). The phase relationships in Table I were computed from n.m.r. measurements of the total liquid-water content of a frozen sample of sea-water.

For the upper temperature range $\left(0^{\circ} \mathrm{C}\right.$ to $\left.-24^{\circ} \mathrm{C}\right)$ the n.m.r. data from the previous paper (Richardson and Keller, 1966) were used. For the lower range $\left(-26^{\circ} \mathrm{C}\right.$ to $-52^{\circ} \mathrm{C}$ ) data from recent experiments were used. These data are shown in Figures 4,5 and 6 . The solid-line curves in all three figures are the results of fourth-order regression analyses of the respective data. Figure 5 is a single regression analysis of the data for the entire lowtemperature range. Figure 6 is the regression analysis of one of the three segments of the lowtemperature range which have distinct curvatures. These segments have temperature ranges $\left(-26^{\circ} \mathrm{C}\right.$ to $-36^{\circ} \mathrm{C},-38^{\circ} \mathrm{C}$ to $-43^{\circ} \mathrm{C},-44^{\circ} \mathrm{C}$ to $\left.-55^{\circ} \mathrm{C}\right)$ which correspond to the precipitation of major salts. Similarly, there are two curved regions $\left(0^{\circ} \mathrm{C}\right.$ to $-7^{\circ} \mathrm{C},-8^{\circ} \mathrm{C}$ to $\left.-23^{\circ} \mathrm{C}\right)$ in the high-temperature range. The regression analysis of each segment produces a better fit of the data, as shown in Figure 4, a composite of the three analyses.

All data points shown are mean values of the n.m.r. data. In Figure 6 some of the data points are shown with extensions to indicate two standard deviations either side $(95 \%)$ range of the data. In all cases where regression analysis was used the equations were tested for fit by $F$ tests and the square of the correlation coefficient was computed, using standard ANOVA techniques. The equations in all cases produced $F$ test results within the $5 \%$ limits. The individual correlation coefficients are presented in the caption for each figure.

In addition to the n.m.r. data, the eutectic temperatures and concentrations of the hydrates (Mellor, 1922-37) were used in the calculations of the phase distributions. This was all of the information required for the computation of Table I, except for the two salts $\mathrm{KCl}$ and $\mathrm{CaCO}_{3}$ which required ion measurements from Gitterman (1937) and Nelson and Thompson (1954). The calcium salt could not be calculated with the other salts because the solubility data are scattered and conflicting.

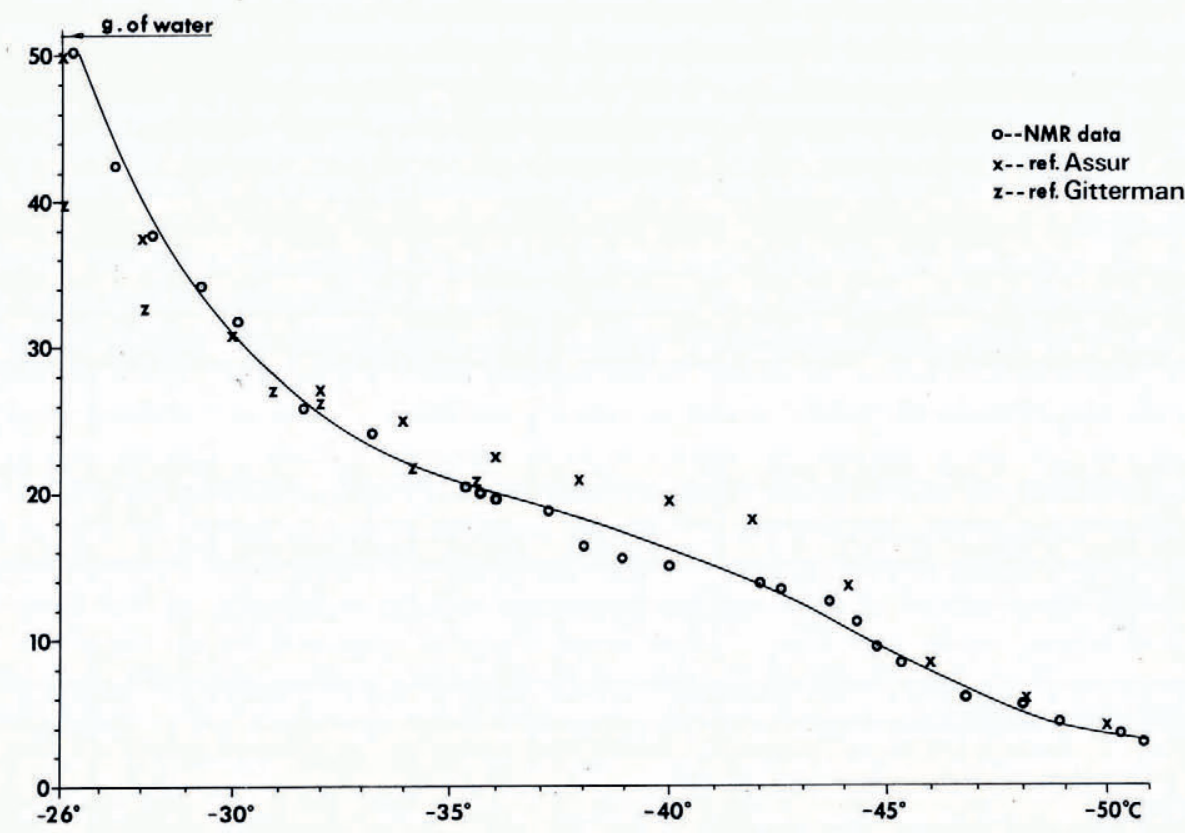

Fig. 5. Liquid-water content of a sample of sea-water measured by an n.m.r. spectrometer. The curce is a fourth-order regression of the n.m.r. data. The other data haze been weighted for differences in salinities. $R^{2}$ is 0.97 . Ref. Assur refers to Assur's table 3 (1.9.5). Ref. Gitterman refers to Gitterman's table 12 (1937). 


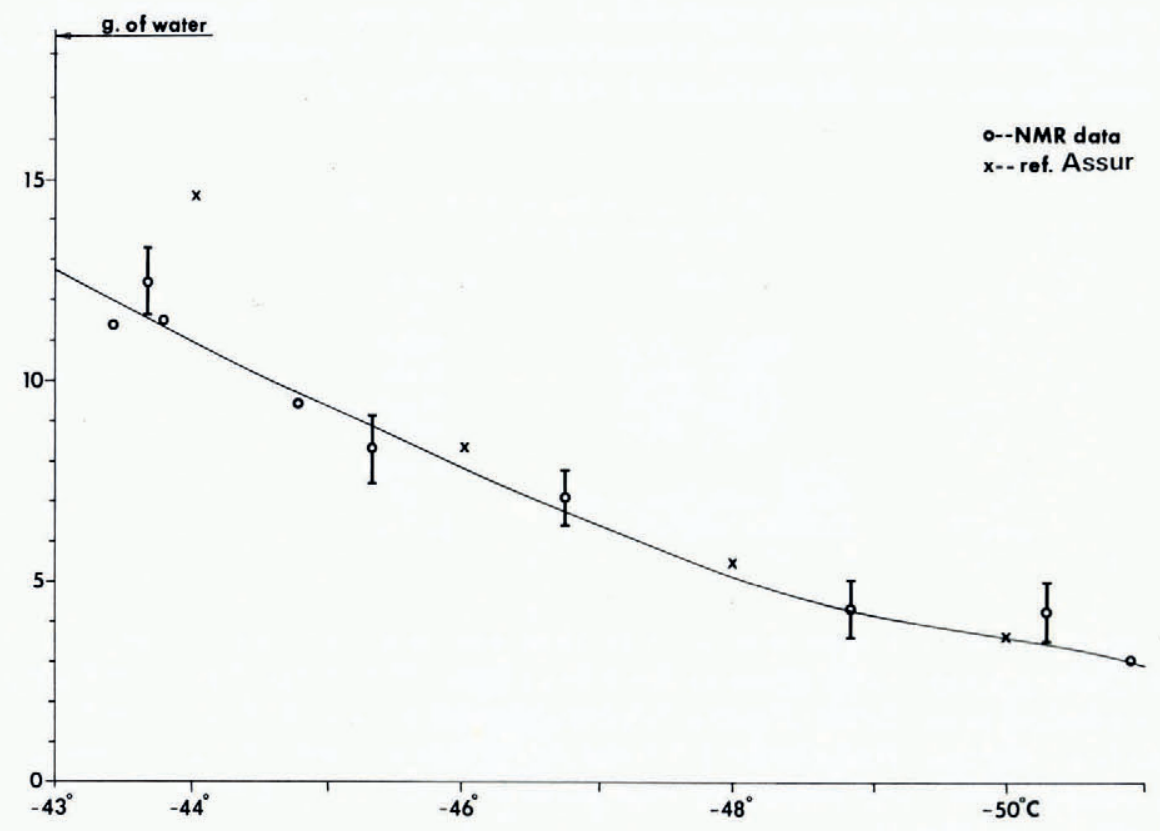

Fig. 6. Liquid-water content of a sea-water sample measured by an n.m.r. spectrometer. The curve is a fourth-order regression of the n.m.r. data. The bars represent a range of two standard deviations either side of the data collected. $R^{2}$ is 0.99 .

After computing the values for potassium chloride and calcium carbonate hexahydrate (columns 12 and 16 ), the total amount of each ion involved in the remaining five salts was computed. For example, using atomic ratios and eutectic concentrations, the distribution of the sodium ions is calculated for each sodium salt. The total amount of sodium ion precipitated per kilogram of sea-water in the form of sodium sulfate decahydrate is given by

$$
\begin{aligned}
& \mathrm{Na}_{\mathrm{s}}{ }^{+}={ }_{10.753} \frac{\mathrm{Na}_{\mathrm{se}^{+}}}{\mathrm{Na}_{\mathrm{se}^{+}+\mathrm{Na}_{\mathrm{ce}}{ }^{+}}} \\
& =\mathrm{r} .25^{8 \mathrm{~g}}
\end{aligned}
$$

where $\mathrm{Na}_{\mathrm{se}}{ }^{+}$is the eutectic concentration of the sodium ion in the decahydrate, and $\mathrm{Na}_{\mathrm{ce}}{ }^{+}$ is the eutectic concentration in sodium chloride dihydrate. The remaining $\mathrm{Na}^{+}, 9.495 \mathrm{~g}$, forms the chloride salts.

A similar computation divides the magnesium ions. Using these values and the values for the chloride ions in potassium chloride and calcium ions in the carbonate salt, the ion distribution for all the salts can be computed, including calcium chloride hexahydrate, which was not listed since its eutectic temperature is $-55^{\circ} \mathrm{C}$.

The total weight of ions in each salt is now used to compute the total amount of bound water that each salt requires for a eutectic concentration. Now the total ionic weight and the bound water for each salt can be used with the n.m.r. data to calculate the values of the hydrates in Table I, except for the next-to-last value for calcium sulfate dihydrate. This latter value occurs at a temperature where three hydrates precipitate simultaneously and the computations become complicated. Fortunately, the precipitation of gypsum nears completion at this temperature so that the changes are very small and the point may be extrapolated from a smooth curve through the final point which is known. Using the graphed 
value for the amount of gypsum precipitated at $-24^{\circ} \mathrm{C}(\mathrm{o} . \mathrm{r} 39 \mathrm{~g})$, the amounts of the other two salts that precipitate at the same temperature may be computed. These calculations illustrate how the values for the precipitated salts were obtained.

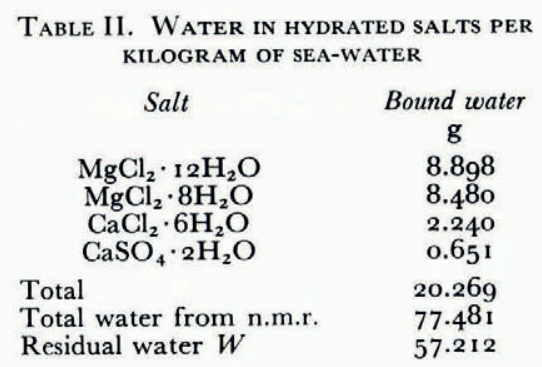

The bound water associated with the salts that precipitate at lower temperatures is first subtracted from the total water given by the n.m.r. data. The remaining water is divided for each salt according to ion ratios. Finally, this bound water is associated with a quantity of ions in the eutectic solution. These individual ions are subtracted from the total ions calculated for the particular salt. The remaining ions go to form the precipitate of that salt at that temperature, as in Table II.

$$
W=w_{\mathrm{es}}+w_{\mathrm{ec}}
$$

where $w_{\mathrm{es}}$ and $w_{\mathrm{ec}}$ are the bound water of the eutectic solutions for $\mathrm{Na}_{2} \mathrm{SO}_{4}$ and $\mathrm{NaCl}$.

$$
\begin{aligned}
w_{\mathrm{es}} & =\frac{\mathrm{I}-C_{\mathrm{es}}}{C_{\mathrm{es}}} S_{\mathrm{s}} \\
& =a S_{\mathrm{s}}
\end{aligned}
$$

where $C_{\mathrm{es}}$ is the eutectic concentration of sodium sulfate.

$$
\begin{aligned}
w_{\mathrm{es}} & =24.974 S_{\mathrm{s}} \\
w_{\mathrm{ec}} & =3 \cdot 348 S_{\mathrm{c}} \\
\frac{W}{w_{\mathrm{ec}}} & =\mathrm{I}+\frac{w_{\mathrm{es}}}{w_{\mathrm{ec}}} \\
& =\mathrm{I}+7.460 \frac{S_{\mathrm{s}}}{S_{\mathrm{c}}}
\end{aligned}
$$

where $S_{\mathrm{s}} / S_{\mathrm{c}}$ is the ratio of the two salts in solution at the preceding temperature

$$
\begin{aligned}
& w_{\mathrm{ec}}=\frac{57.212 \mathrm{~g}}{1.049^{2}}=54.5^{29} \mathrm{~g} \\
& w_{\mathrm{es}}=57.212 \mathrm{~g}-54.5^{29} \mathrm{~g}=2.683 \mathrm{~g} .
\end{aligned}
$$

The amount of ions of the salt remaining in solution is

$$
\begin{aligned}
S_{\mathrm{s}} & =\frac{w_{\text {es }}}{a} \\
& =\frac{2.683 \mathrm{~g}}{24.974}=0.1074 \mathrm{~g} .
\end{aligned}
$$


The amount of ions precipitating in the hydrate, $h_{\mathrm{s}}$, is given by the difference between the total ions of the salt $T_{\mathrm{s}}$ in the eutectic solution and those left in solution

$$
\begin{aligned}
h_{\mathrm{s}} & =T_{\mathrm{s}}-S_{\mathrm{s}} \\
h_{\mathrm{s}} & =3.880 \mathrm{~g}-0.107 \mathrm{~g} \\
& =3.773 \mathrm{~g} .
\end{aligned}
$$

The total weight of the hydrate is

$$
\begin{aligned}
H_{\mathrm{s}} & =\frac{3.773 \mathrm{~g}}{0.44 \mathrm{I}} \\
& =8.554 \mathrm{~g} \mathrm{Na}_{2} \mathrm{SO}_{4} \cdot 1 \mathrm{OH}_{2} \mathrm{O} .
\end{aligned}
$$

This value compares to $8.509 \mathrm{~g}$ obtained from the ion data of Nelson and Thompson (1954). Values for the other five hydrates were calculated in a similar manner. The tabulated values in Table I were obtained from fourth-order regression analysis of the calculated points. After the tabulated values for the hydrates were obtained, the remaining columns in Table I were readily calculated.

Under the original assumption that the residual and entrapped brine have the same composition, the salinity measurements of Gitterman (1937), Nelson and Thompson (1954) and Ringer (1906) offer an opportunity to compare the results of Table I with experimental

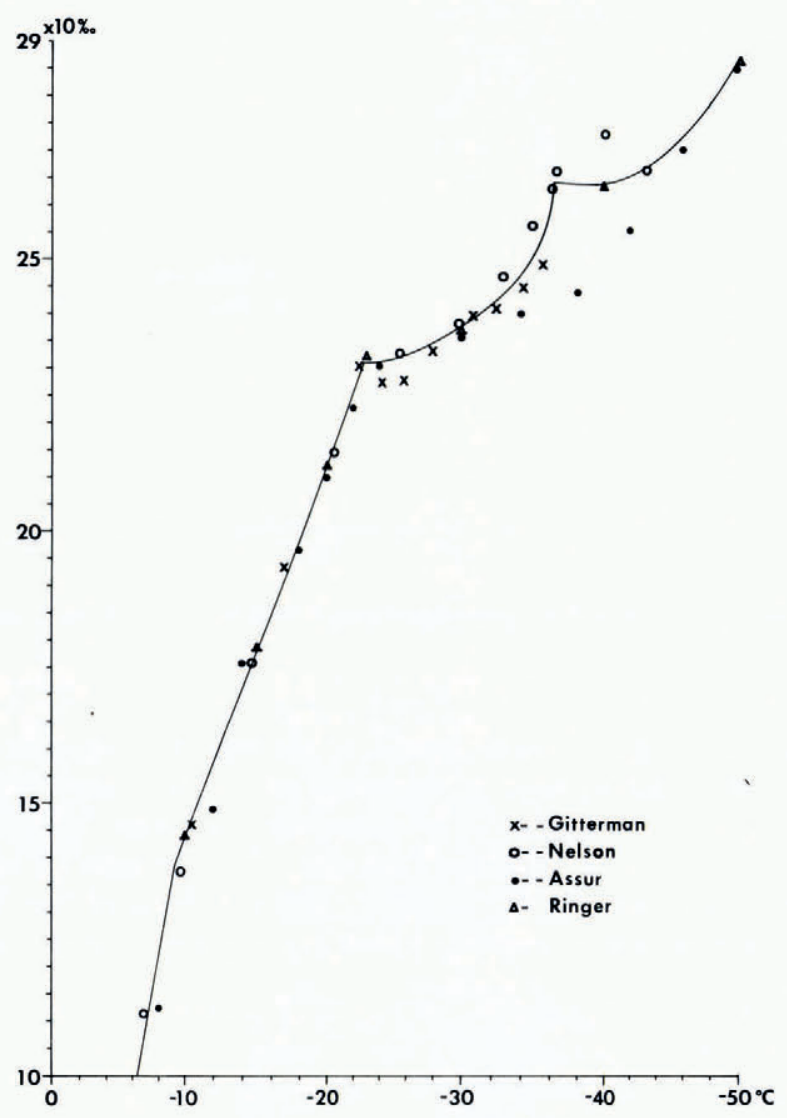

Fig. 7. The salinity curve for brine at sub.freezing temperatures. The first two segments are linear regressions of the experimental data. The upper two segments are fourth-order regressions of the experimental data. The $R^{2}$ are $0.99,0.99,0.98$ and 0.97 . 
data. Figure 7 is a compilation of the three authors' measurements. Assur's computed values are included for reference. The graph consisting of two linear segments and two curved segments was constructed from two linear regressions and two fourth-order regressions of the respective data. Figure 8 is a comparison of the regression results with the values from Table $I$.

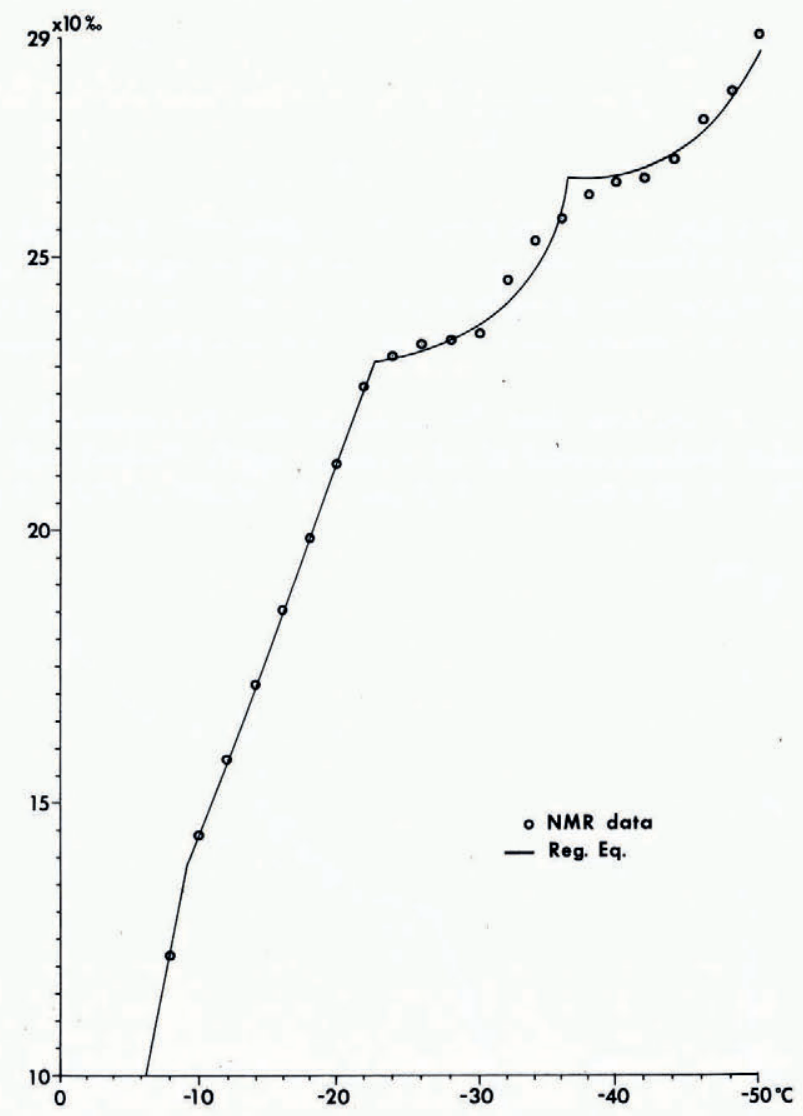

Fïg. 8. A comparison of the experimental curies from Figure 7 with the computed calues based upon the n.m.r. data.

\section{Conclusions}

Nuclear magnetic resonance measurements of the liquid-water content of sea ice were used to compute the phase relationships as functions of temperature. The computations werc based upon a binary salt mixture used as a model for sea-water. These salts have their solvation water bound in a pseudo-crystalline structure. The amount of solvation water is based upon the eutectic concentrations of the salts. On the basis of the salinity comparison in Figure 8, this model produced results which are in good agreement with experimental salinity data.

The model and the n.m.r. dat established new evidence for the addition of two controversial hydrates to the list of precipitating salts. Assur (I958) first postulated the octahydrate of magnesium chloride. Solubility and n.m.r. data appear to confirm the precipitation of this salt. Gitterman's (1937) proposed dihydrate of calcium sulfate also appears to be confirmed by the n.m.r. results, although the solubility data on this salt are incomplete and therefore the reported amounts of this precipitate were based upon an estimate of eutectic conditions. 


\section{ACKNOWLEDGEMENTS}

The author wishes to express his appreciation to Dr W. K. Lyon, Director of the Arctic Submarine Laboratory, for his support of this project. Also, acknowledgement is made of the support of the U.S. Naval Undersea Cienter's Independent Research Project.

MS. received 4 June 1975 and in revised form 5.7 anuary 1976

\section{REFERENCES}

Anderson, D. L. 1960. The physical constants of sea ice, Research, Vol. 13, No. 8, p. 310-18.

Assur, A. 1958. Composition of sea ice and its tensile strength. Washington, D.C., p. 106-38. (In Arctic sea ice ([U.S.] National Academy of Sciences-National Research Council Publication 598.))

Conway, B. E.. and Barradas, R. G. 1966. Chemical physics of ionic solutions. New York, John Wiley and Sons, Inc.

Gitterman, K. E. 1937. Termicheskiy analiz morskoy vody [Temperature analysis of sea-water]. Trudy Solyanoy Laboratorii, Vyp. 15, Chast' 1, p. 5-23.

Mellor, J. W. 1922-37. A comprehensive treatise on inorganic and theoretical chemistry. 16 vols. London, Longmans Green and Co.

Nelson, K. H., and Thompson, T. G. 1954. Deposition of salts from sea water by frigid concentration. Fournal of Marine Research, Vol. 13, No. 2, p. 166-82.

Richardson, C., and Keller, E. E. 1966 . The brine content of sea ice measured with a nuclear magnetic resonance spectrometer. Fournal of Glaciology, Vol. 6, No. 43, p. 89-100.

Ringer, W. E. 1906. De veranderingen in samenstelling van zeewater bij het bevriezen. Chemisch Weekblad, Jaarg. 3, Nr. I 5, p. 223-49.

Ringer, W. E. 1928. Über die Veränderungen in der Zusammensetzung des Meereswassersalzes beim Ausfrieren. Rapports et Procès-verbaux des Réunions. Conseil Permanent International pour l'Exploration de la Mer, Vol. 47, p. $226-31$.

Savel'yev, B. A. I963[a]. Rukovodstvo po izucheniyu svoystv l'da |Mamual for the study of the properties of ice]. Moscow, Izdatel'stvo Moskovskogo Universiteta.

Savel'yev, B. A. $1963[\mathrm{~b}]$. Stroyeniye, sostav i svoystva ledyanogo pokrova morskekh i presnykh vodeomov [Structure, composition and properties of ice cover of sea and fresh waters]. Moscow, Izdatel'stvo Moskovskogo Universiteta.

Thompson, T. G., and Nelson, K. H. 1956. Concentration of brines and deposition of salts from sea water under frigid conditions. American Journal of Science, Vol. 254, No. 4, p. 227-38. 